\title{
PELAKSANAAN ISBAD NIKAH DAN DISPENSASI NIKAH DI KOTA PADANG
}

\author{
SRI AGUSTINI \\ Sekolah Tinggi Ilmu Hukum Padang \\ titinposmetro@gmail.com
}

\begin{abstract}
Marriage is a marriage bond (contract) carried out in accordance with the provisions of Islamic law and teachings. Meanwhile, marriage is a marriage ceremony that is identified with the consent and kabul process. Literally, marriage is a sacred bond and is carried out by a combination of religious and state regulations. In order for the marriage bond to have legal certainty administratively, the marriage has been regulated in law. With the enactment of these rules, marriages that are not in accordance with the law cause their own problems in society. Especially about unregistered marriages and early marriage or marriages by minors.
\end{abstract}

Keywords: Isbad Nikah, Marriage Dispensation, Padang City

Abstrak: Nikah adalah ikatan (akad) perkawinan yang dilakukan sesuai dengan ketentuan hukum dan ajaran agama islam. Sedangkan pernikahan adalah upacara nikah yang diidentikan dengan proses ijab dan kabul. Secara harfiah, pernikahan merupakan ikatan suci dan dilaksakan dengan kombinasi antara aturan agama dan negara. Agar ikatan pernikahan mempunyai kepastian hukum secara administrasi, maka pernikahan telah diatur dalam undang-undang. Dengan diberlakukannya aturan tersebut, pernikahan yang tak sesuai dengan undang-undang menimbulkan problema tersendiri dalam masyarakat. Terutama tentang pernikahan yang tak tercatat dan pernihan dini atau pernikahan yang dilakukan anak dibawah umur.

Kata Kunci: Isbad Nikah, Dispensasi Nikah, Kota Padang

\section{A. Pendahuluan}

Sebagai ibukota propinsi yang memiliki penduduk 1 juta jiwa, masalah pernikahan di Kota Padang cukup tinggi. Tak hanya angka perceraian yang terus bertambah, berbagai problematika pernikahan yang diselesaikan oleh lembaga Pengadilan Agama Padang juga banyak. Salah satunya adalah pernikahan yang tak tercatat secara administrasi yang pada akhirnya diselesaikan dengan Isbad Nikah dan pernikahan oleh anak tak cukup umur yang diselesaikan dengan dispensasi nikah.

Saat ini, jumlah permohonan yang masuk ke Pengadilan Agama Padang untuk kedua masalah tersebut cukup tinggi. Data dari web resmi Pengadilan Agama Padang, di tahun 2020 jumlah permohonan isbad nikah yang telah diselesaikan oleh lembaga tersebut adalah sebanyak 225 permohonan. Sementara untuk pemohonan dispensasi nikah adalah sebanyak 61 perkara. Tingginya angka ini mengundang penulis untuk membuat tulisan ini menjadi suatu penelitian.

\section{B. Metodologi Penelitian}

Untuk melakukan penelitian ini dan untuk melengkapi bahan-bahan atau data yang kongkrit, jawaban yang objektif dan ilmiah serta dapat dipertanggungjawabkan kebenarannya, maka penulis menggunakan metode penelitian pendekatan yuridis normatif. 


\section{Hasil dan Pembahasan \\ 1. Isbad Nikah}

Kata Isbad nikah adalah kutipan dari bahasa Arab yang dalam bahasa Indonesia dapat diartikan sebagai Pengesahan Nikah atau Pengesahan Perkawinan. Isbad Nikah dalam pengertian ini adalah pengesahan dan pembuktian tentang telah terjadinya pernikahan secara administratif, karena hukum asal pernikahan adalah hukum syara' yang menentukan sah atau tidaknya suatu perkawinan, dan akan menimbulkan akibat hukum di dunia dan diakhirat. Sedangkan pengesahan oleh undang-undang perkawinan sifatnya hanya tambahan agar perkawinan itu tidak liar dan dapat dipertannggungjawabkan secara administratif.

Isbad Nikah muncul dari problematika Undang-undang Perkawinan Indonesia yang menilai sah atau tidak sahnya perkawinan adalah dari segi terpenuhi atau tidaknya aturan agama yang mengatur tentang pernikahan itu. Yang terdiri dari rukun dan syarat perkawinan. Sementara di sisi lain undang-undang juga menyaratkan sahnya perkawinan itu apabila tercatat di lembaga resmi yang ditunjuk untuk itu. Perkawinan yang tidak tercatat dianggap perkawinan liar dan tidak mempunyai kekuatan hukum. Agar perkawinan itu tidak dianggap liar, dapat dilakukan upaya hukum pencatatannya melalui Isbad Nikah di Pengadilan Agama.

Kewenangan Pengadilan Agama mengenai Isbad Nikah pada awalnya diperuntukan bagi mereka yang melakukan perkawinan tidak tercatat sebelum berlakunya undang-undang nomor 1 tahun 1974 tentang Perkawinan. Kemudian kewenangan pengadilan agama tersebut berkembang dan diperluas dengan berlakunya Inpres No 1 tahun 1991 tentang Kompilasi Hukum Islam (KHI).

Pasal 7 ayat (2) Kompilasi Hukum Islam menyebutkan " Dalam hal perkawinan tidak dapat dibuktikan dengan Akta Nikah dapat diajukan Isbad Nikahnya ke Pengadilan Agama." Pasal 7 ayat (3) KHI menyebutkan : Isbad Nikah yang dapat diajukan ke Pengadilan Agama terbatas mengenai hal-hal yang berkenaan dengan :

a. Adanya perkawinan dalam rangka penyelesaian perceraian

b. Hilangnya Akta Nikah

c. Adanya keraguan tentang sah atau tidaknya salahsatu syarat perkawinan

d. Adanya perkawinan yang terjadi sebelum berlakunya Undang-undang Nomor 1 Tahun 1974

e. Perkawinan yang dilakukan oleh mereka yang tidak mempunyai halangan perkawinan menurut Undang-undang Nomor 1 tahun 1974.

Perkawinan yang dilarang menurut pasal 8 Undang-undang Nomor 1 tahun 1974 adalah

a. Berhubungan darah dalam garis keturunan lurus kebawah ataupun ke atas

b. Berhubungan darah dalam garis keturunan menyamping, yaitu antara saudara, antara seseorang dengan saudara orangtua dan anatara seorang dengan saudara neneknya.

c. Berhubungan semenda, yaitu mertua, anak tiri, menantu dan ibu/bapak tiri.

d. Berhubungan susuan, yaitu orangtua susuan, anak susuan, saudara susuan dan paman/bibi susuan.

e. Berhubungan saudara dengan istri atau sebagai bibi atau kemenakan dari istri, dalam hal seorang suami beristri lebih dari seorang 
f. Mempunyai hubungan yang oleh agamanya atau peraturan lain yang berlaku dilarang kawin.

Hikmah yang terkandung dari Isbad Nikah adalah persetujuan dengan hikmah perkawinan yang tercatat secara resmi di Kantor Urusan Agama (KUA) diantaranya adalah :

a. Terciptanya Ketertiban Hukum.

Dengan adanya pencatatan nikah menjadi pengikat agar tidak terjadi perkawinana atau perceraian secara semena-mena dan mencegah terjadinya perkawinan liar. Seorang laki-laki terbatas boleh beristri paling banyak empat orang dan seorang perempuan tidak boleh bersuami lebih dari satu orang. Apabila pernikahan terjadi di luar ketentuan tersebut maka hukumnya haram.

b. Adanya Kepastian Hukum

Dengan tercatatnya perkawinan dan adanya Akta Nikah memberikan kepastian hukum tentang hak dan kewajiban suami istri dan anak-anak mereka serta orang yang terkait dengan perkawinan itu. Seperti nafkah anak dan istri, hak atas harta bersama, hak atas kewarisan dan lain-lain.

c. Terciptanya perlindungan hukum.

Dengan adanya Akta Nikah yang dapat memberikan perlindungan hukum terhadap upaya pengingkaran oleh pihak-pihak yang tidak bertanggung jawab untuk lepas dari ikatan perkawinan atau untuk menjadikan perkawinan terkatungkatung. Akta Nikah juga jadi perlindungan hukum bagi anak mereka terkait dengan identitas keturunan.

d. Terlepas dari jerat hukum

Pasal 45 huruf (a) Peraturan pemerintah Nomor 9 Tahun 1975 menyebutkan bahwa perkawinan yang tidak tercatat dihukum dengan hukuman denda. Artinya. Pertikahan yang tidak tercatat secara resmi merupakan perbuatan melawan hukum dan dapat dikenakan sanksi hukum.

\section{Dispensasi Nikah}

Dispensasi menurut KBBI adalah pengecualian dari aturan karena adanya pertimbangan yang khusus; pembebasan dari suatu kewajiban atau larangan. Sementara menurut bahasa dispensasi pernikahan adalah melunakan rintangan yang melarang atau membatalkan sebuah pernikahan dalam sebuah kasus khusus. Undangundang telah dengan jelas mengatur syarat-syarat serta tata cara pernikahan. Namun undang-undang itu juga mengatur penyimpangan dari aturan yang semestinya apabila pernikahan itu harus sesegera mungkin dilaksanakan.

Dispensasi nikah adalah pemberian hak kepada seseorang untuk menikah maupun usianya belum mencapai batas minimal yang ditentukan oleh undang-undang. Batas usia minimal pernikahan menurut ketentuan Undang-undang Nomor 16 Tahun 1974 adalah, usia pria minimal 19 tahun dan usia wanita minimal 16 tahun. Namun berdasarkan undang-undang Nomor 16 tahun 2019 Tentang Perubahan Terhadap Undang-undang Nomor 1 Tahun 1974 usia pernikahan disejajarkan antara pria dan wanita. Yakni sama-sama usia 19 tahun. Dalam undang-undang ini ditetapkan seseorang baik pria maupun wanita baru boleh menikah seteah berusia minimal 19 tahun.

Dalam hal-hal yang mendesak karena keadaan tertentu, seperti antara seorang pria dengan wanita berpacaran sudah terlalu akrab, sehingga dikhawatirkan akan terjerumus pada hal-hal yang dilarang, atau ternyata sudah terjerumus pada hal yang 
dilarang, atau karena orangtua dan keluarga sudah tidak mampu lagi mencegah prilaku anaknya, sehinggga dikhawatirkan akan membuat malu di tengah masyarakat atau akan dikucilkan masyarakat sebagai sanksi sosial, dan setelah diurus pernikahan ternyata Pegawai Pencatat Nikah di Kantor Urusan Agama (KUA) setempat tidak mau menikahkannya dengan alasan usia calon mempelai pria atau wanita atau keduanya belum mencapai batas minimal usia perkawinan. Jalan keluarnya adalah bukanlah nikah liar atau nikah sirri atau nikah di bawah tangan atau kawin lari dan sebagainya. Melainkan menikah berdasarkan Dispesasi Nikah yang dikeluarkan oleh Pengadilan Agama bagi yang beragama islam dan Pengadilan Negeri bagi yang beragama selain Islam.

Pengadilan agama diberi kewenangan oleh Undang-undang untuk memberikan Dispensasi Nikah bagi calon mempelai yang belum mencapai batas minimal usia perkawinan yang ditentukan Undang-undang yaitu 19 tahun setelah mendengar keterangan kedua calon mempelai, orangtua kedua belah pihak dan saksi-saksi dipersidangan. Dengan Dispensasi Nikah yang dikeluarkan oleh Pengadilan Agama tersebut, Pegawai Pencatat Nikah pada Kantor Urusan Agama (KUA) yang ditunjuk berwenang untuk menikahkan kedua calon mempelai tersebut meskipun usianya belum mencapai 19 tahun.

\section{Wali Adhal}

Apabila wani nasab enggan ( dalam bahasa arab disebut adhal) maka si wanita dapat mengajukan permohonan pada wali adhal ke Pengadilan Agama. Dan apabila permohonanya dikabulkan oleh Pengadilan Agama maka Pengadilan Agama akan menunjuk kantou urusan agama di wilayah hukum tempat tinggalnya untuk menikahkannya dengan wali hakim. Wali hakim baru dapat bertindak sebagai wali nikah apabila wali nasab tidak ada atau tidak mungkin menghadirkannya atau tidak diketahui tempat tinggalnya atau gaib atau enggan ( pasal 2 ayat (1) Kompilasi Hukum Silam. Wali Hakim adalah wali yang ditunjuk oleh negara karena jabatannya yaitu Kepala Kantor Urusan Agama atau yang ditunjuk olehnya. Orang lain tidak berhak jadi wali hakim.

\section{Penutup}

Setiap permasalahan pernikahan sudah diatur oleh Undang-undang. Maka pernikahan yang tidak dilakukan menurut Undang-undang dianggap sebagai nikah liar dan tidak mempunyai kepastian hukum dan perlindungan hukum bahkan sebaliknya merupakan suatu perbuatan melanggarkan hukum dan dikenakan sanksi hukum. Maka dari itu, setiap warga negara diharapkan menikah secara resmi di KUA dan bercerai secara resmi di Pengadilan Agama. Bagi pernikahan yang tidak tercatat dapat diisbadkan di Pengadilan Agama, dan bagi pernikahan yang ditolak oleh KUA karena belum cukup umur dapat dimintakan Dispensasi nikahnya di Pengadilan Agama. Undang-undang telah membatasi usia pernikahan yaitu 19 tahun. Hal ini menjadi tanggungjawab orangtua, guru dan masyarakat agar seketat mungkin mengendalikan dan mengawasi pergaulan anak-anak agar tidak terjurumus kepada hal-hal yang memaksa harus segera menikah padahal usia belum mencapai batas minimal usia perkawinan. 


\section{Daftar Pustaka}

Bunyamin Mahmuddin, Hukum Perkawinan Islam, Pustaka Setia, Jakarta, 2017.

Syarifuddin Amir, Hukum Perkawinan Islam di Indonesia, Prenada Media, Jakarta, 2014

Syahurri Taufiqurrohman, Legislasi Hukum Perkawinan di Indonesia, Prenada Media Grub, 2017

Zainuddin, Perkawinan Dalam Syariat Islam, Pendidikan Deepublish, 2017

Hamdi, Hukum Perkawinan Islam di Indonesia, Pendidikan Deepublish, 2018

Undang-Undang Nomor 1 Tahun 1974 tentang Perkawinan

Kamus Besar Bahasa Indonesia Online 